Rapp. Gronlands geol. Unders. 48, 85-91 (1972)

\title{
REPORT ON INVESTIGATIONS OF TERTIARY SEDIMENTS AT KAP BREWSTER, SCORESBY SUND, EAST GREENLAND
}

\author{
K. Birkenmajer
}

\section{Introduction}

Sediments associated with Tertiary basalts were suspected to occur at Kap Brewster, Scoresby Sund, since W. Scoresby's expedition brought back pieces of charcoal, and $\mathrm{O}$. Nordenskjöld and P. Koch found there numerous fossil tree trunks lying loose in basalt scree (Mathiesen, 1932). The sediments, with a marine fauna partly comparable with those known already from Kap Dalton (Ravn, 1933), were located at Kap Brewster by D. Mackeney and F.W. Sherrell, members of Lauge Koch's expedition in 1951. Hassan (1953) described the fossils collected by them and gave a fairly detailed description of the geology of the area based on their field report. In ascending order he distinguished: (A) the infra-basalt sediments (age unknown), (B) the plateau basalts (Tertiary, with sediment intercalations), (C) the Kap Dalton 'series' (subdivided into the 'Cyrena beds' Middle-Upper Eocene, and the 'Coeloma beds' - probably Lower Oligocene), and (D) the Kap Brewster 'series' ('Chlamys beds' - probably Miocene). The relationships between these units were not determined. This was, therefore, the aim of the present author's visit in 1971 within the mapping programme of the Geological Survey of Greenland. B. Buchardt Larsen assisted the author in the field, and his help is acknowledged here with pleasure.

\section{Structure}

The area of Tertiary basalts and sediments adjoining Kap Brewster, i. e. Savoia Halvø, is cut by a major fault trending NNE (fig. 13). The fault plane is exposed best at Muslingehjørnet where it dips $85^{\circ}-90^{\circ}$ towards the south-east and a crushbreccia and mylonite (basaltic material) about $30 \mathrm{~m}$ thick are exposed. This is a dip-slip normal fault with the throw of more than $1000 \mathrm{~m}$. 


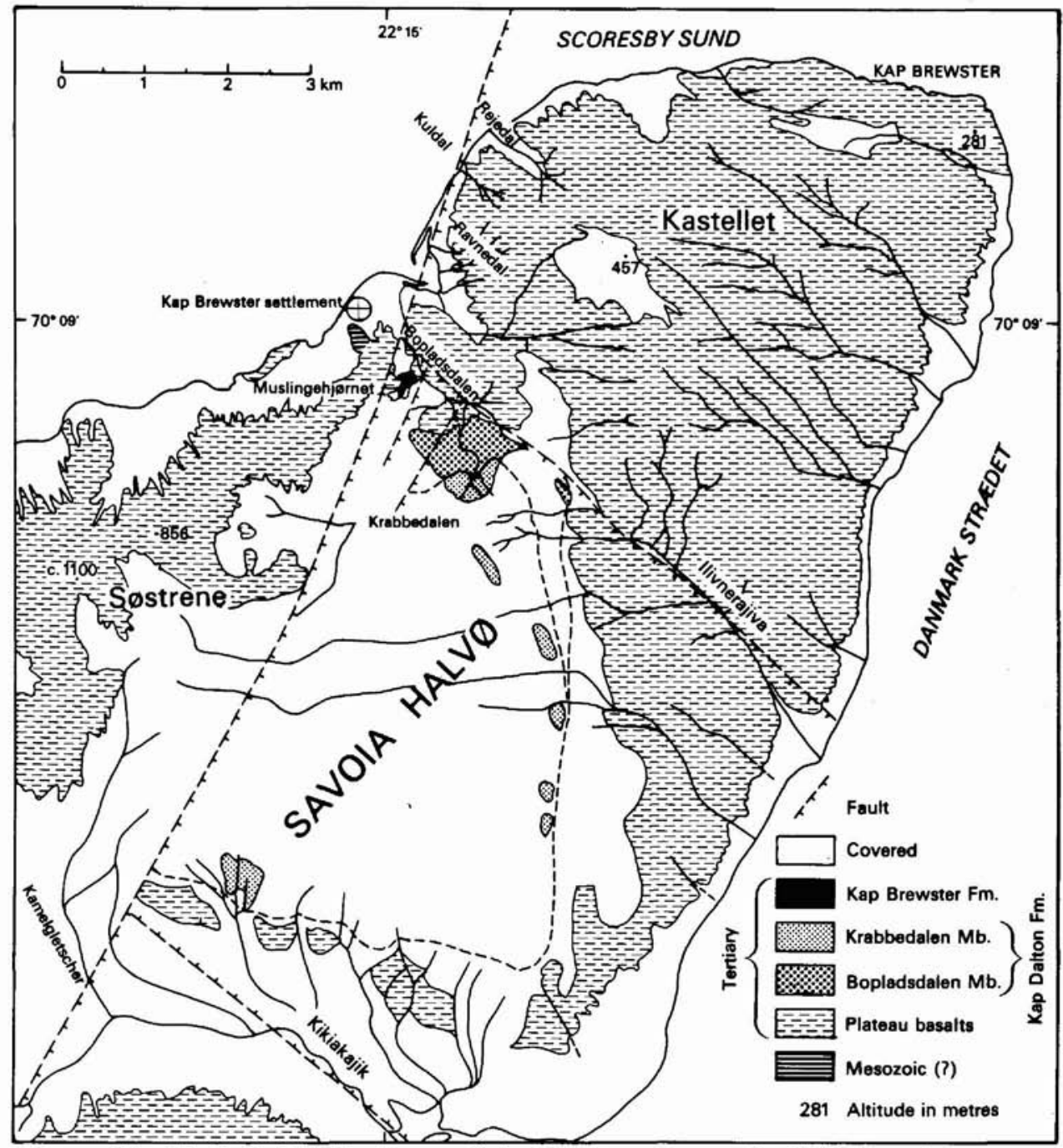

Fig. 13. Geological sketch-map of the Kap Brewster area, by K. Birkenmajer.

To the north-west of the Muslingehjørnet fault, the upthrown Søstrene block consists of a nearly horizontal pile of basalt lava flows with a few thin sedimentary intercalations, altogether more than $1100 \mathrm{~m}$ thick. The basalts are underlain by shales of probably Mesozoic age (infra-basalt sediments - see below).

To the south-east of the Muslingehjørnet fault, the downthrown Kastellet block consists of a pile of basalt lava flows with subordinate thin sediment and tuff intercalations, altogether more than $500 \mathrm{~m}$ thick. The basalts are conformably capped by fossiliferous sediments which post-date the period of volcanic activity of 
the area, and are represented by the Kap Dalton and Kap Brewster formations. These sediments, which are the youngest Tertiary formations of East Greenland, occur at Savoia Halvø in a shallow graben delimited in the west by the Muslingehjørnet fault, and in the north and south by the Kíkiakajik and Bopladsdalen faults respectively; both these last named faults trend southeastwards. The Bopladsdalen fault is well exposed towards the north-west where it is a dip-slip normal fault with a throw of probably about $50 \mathrm{~m}$. The fault plane dips $55^{\circ}-85^{\circ}$ towards the south-west and is accompanied by a slickensided crushbreccia.

The basalt lava flows exposed north-east of the Bopladsdalen fault (at Kastellet and Kap Brewster) dip $5^{\circ}-20^{\circ}$ (on average $10^{\circ}$ ) towards the south-west, locally towards the west. To the south-west of the Bopladsdalen fault, i. e. in the graben, the basalt flows dip $5^{\circ}-20^{\circ}$ (on average $10^{\circ}$ ) towards the west. The sediments of the Kap Dalton Formation dip conformably with the basalts, and only close to the Muslingehjørnet fault do they dip in an opposite direction $-20^{\circ} \mathrm{E}$ - thus forming a small syncline. Two additional faults, probably radiating from the Muslingehjørnet fault, cut here through the Kap Dalton sediments and the underlying basalts.

The sediments of the Kap Brewster Formation occupy a special position within the downthrown block, which will be discussed later.

\section{Substratum of the basalt complex}

The substratum of the basalt complex is exposed only at Kap Brewster settlement (infra-basalt series of Hassan, 1953). Immediately south of the westernmost hut, under the vertical face of basalt lava flows of Muslingehjørnet, poor exposures of sediments can be seen up to 72-75 m a. s. 1 . The best exposures are between 45 and $65 \mathrm{~m}$ a. s. 1., but it seems justified to regard the whole scree-covered slope between the shore and the lowermost basalt flow in the cliff to be built up of almost horizontal sediments, a sequence thus a minimum of $75 \mathrm{~m}$ thick. These are dark grey to dark blue silty shales, easily friable, with very fine-grained mica. At about $50 \mathrm{~m}$ a. s. 1. they contain an intercalation $2.5 \mathrm{~cm}$ thick of fine-grained calcareous sandstone to siltstone, weathering yellow. Probably this level was the source of the spatangid echinoids mentioned by Hassan (1953).

Compared to sediment intercalations within the basaltic complex, and to the Tertiary sediments post-dating the basalts, the infra-basalt shales at Kap Brewster settlement are much more diagenesized and compact. They resemble very much some of the Jurassic and Cretaceous shales of Jameson Land. Samples for microfaunal investigations have been taken from the shales in question.

The contact of the shales with the overlying basalts is covered by scree, but 5-7 $\mathrm{m}$ below the first exposure of the lava the shales are slightly baked and are weathered brown. 


\section{Plateau basalt complex}

The plateau basalt complex starts at Kap Brewster settlement with black finegrained basalt flows with irregular columns, sometimes with pillow structures at the base. In the Søstrene block there are a minimum of 50 lava flows, from 1-2 to about $50 \mathrm{~m}$ thick. Most of the flows show well developed columns in the lower portion and scoria, often passing into tuff, in the upper parts. There are some zones richer in zeolites and agate filling voids in the scoria. These may be used for local correlation of the flows. A few (3-4) feebly cemented sandy sediment intercalations, usually baked or silicified, occur in the middle part of the basalt complex at Muslingehjørnet where they are at most 2-3 m thick.

Tarling (1967) presented palaeomagnetic characteristics for 24 basalt flows at Muslingehjørnet sampled by Fawcett et al. (1966). These flows have not yet been radiometrically dated, and samples were therefore taken from the second lowest flow of the Søstrene block in 1971.

In the downthrown Kastellet block there are a minimum of 30 lava flows ranging in thickness from 1 to $30-50 \mathrm{~m}$. Most of the flows show well developed columns (sometimes arranged radially) in the lower parts, and scoria in the upper parts. The majority of the flows are either glassy or fine-grained basalts, but some, especially close to the top of the succession, are coarse-porphyritic (feldsparphyric). Pahoehoe structures have been recognised in the middle part of the lava succession south of Kastellet, and this is also a zone very rich in large quartz druses and agate. Red products of Tertiary weathering are characteristic for many tops of lava flows of the highest 15 flows.

The lowest exposures of the minimum $500 \mathrm{~m}$ thick lava sequence of Kastellet (bottom not exposed at sea level, the base of the northern cliff) have been dated radiometrically by Beckinsale et al. (1970). In a vertical traverse of one flow the fine-grained upper and lower contacts gave K-Ar dates $58 \pm 3 \mathrm{~m}$. y. (average of two argon determinations) and $56 \pm 2 \mathrm{~m}$. y. which are likely to be good approximations of the true age. This indicates an Upper Paleocene age from the middle part of the lava succession at Savoia Halvø according to the Geological Society Phanerozoic time scale of 1964 . Samples for palaeomagnetic measurements and radiometric dating were taken in 1971 from the highest basalt flow, 12-15 m thick, exposed close to the bottom of the Kap Dalton sediments.

There are 5-6 sedimentary intercalations $0.5-5 \mathrm{~m}$ thick, partly baked by lava or silicified, in the upper $200-300 \mathrm{~m}$ of the basalt succession of the Kastellet block. These are usually yellow siliceous shales, sometimes also sands and coal-bearing clays. Some of the coals are autochthonous as shown by plant rootlets in the sediment, the others redeposited. Silicified driftwood fragments with Teredo borings occur often in the upper flows. These indicate a near-shore, shallow-marine environment for some effusions.

It has not been possible to correlate the lava flows across the Muslingehjørnet 
fault with any degree of accuracy. The lack of bright red scoria between the flows at the top of Søstrene $(c .1100 \mathrm{~m})$ may indicate, however, that these flows are probably older than the topmost $c .15$ flows (altogether 100-150 m thick) of the Kastellet block. Thus the thickness of the whole succession of plateau basalts at Savoia Halvø would amount to a minimum of $1200-1250 \mathrm{~m}$.

\section{Kap Dalton Formation}

The sediments decribed in detail by Hassan (1953) as the Kap Dalton 'series' are here formally renamed the Kap Dalton Formation, and subdivided into two members: the lower Bopladsdalen Member and the upper Krabbedalen Member.

The Bopladsdalen Member about $80 \mathrm{~m}$ thick includes the basal conglomerate (layer No. 4 of Hassan) and the 'Cyrena beds' (layers 5a-e of Hassan). The contact of the basal conglomerate with the plateau basalt complex is well exposed in the upper part of Bopladsdalen, above the lake. On the eastern slope occurs a zone of

Table 5. Tertiary succession at Kap Brewster

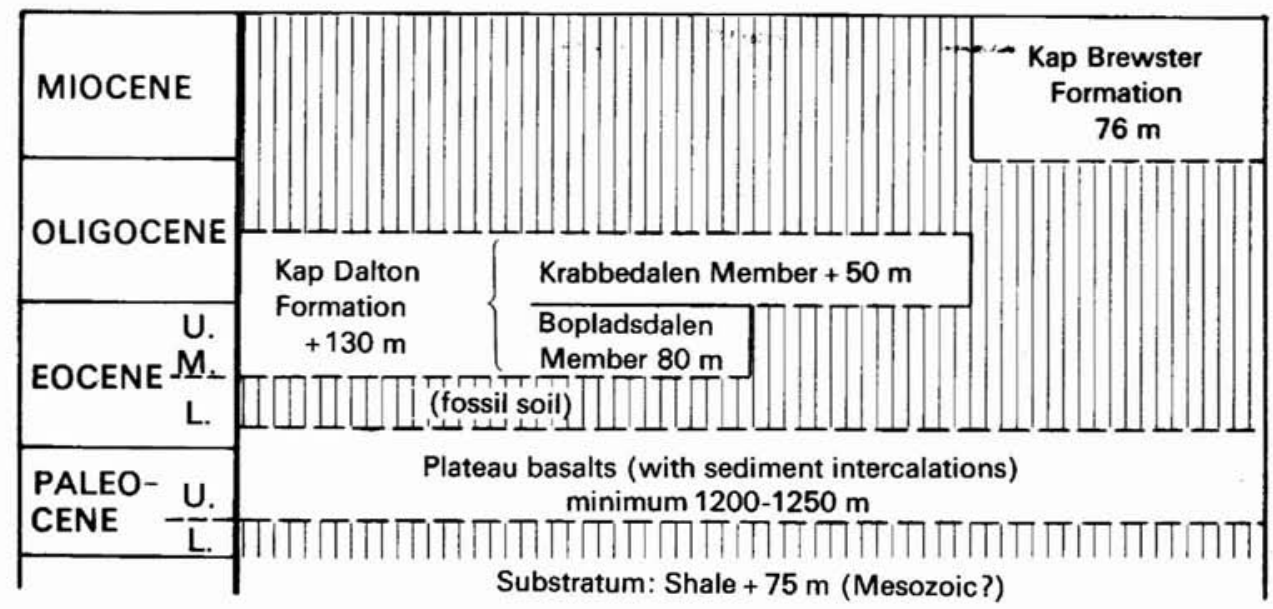

strongly weathered basalt $11 \mathrm{~m}$ thick, above which follows a thin layer $(1.5 \mathrm{~m})$ of fossil soil composed of local material (weathered basalt) and yellow to rusty orange silts with thin carbon-rich laminae. The basal conglomerate of the Kap Dalton Formation (Bopladsdalen Member) is up to $2 \mathrm{~m}$ thick. It consists of very well rounded pebbles (pebble-lag concentrate) of predominantly grey fine-grained basalt in poor, feebly cemented basalt detritus, sometimes with mollusc-shell detritus and carbonized wood. There follow yellow-weathered, flaggy sandstones with marine and brackish molluscs, also with pieces of wood with Teredo borings 
and with scattered basalt pebbles. The fauna indicates a Middle-Upper Eocene age (Hassan, 1953).

The Bopladsdalen Member forms a wedge thickest at Bopladsdalen $(80 \mathrm{~m})$ and disappearing towards the south at a distance of barely $3 \mathrm{~km}$. The character of the deposits and their fauna indicates a brackish-water to shallow-marine environment. This seems to be a part of a delta deposited in an estuary by a river flowing from the north or the west.

The Krabbedalen Member is a new name for the 'Coeloma beds' (layer No. 6) of Hassan (op. cit.). The member is about $50 \mathrm{~m}$ thick at Krabbedalen where it consists of alternating grey to yellowish marly siltstones and hard calcareous siltstones often with single pebbles of basalt or other rocks. A rich shallow-marine fauna indicates a probably Lower Oligocene age (Hassan op. cit.). The Krabbedalen Member occupies a fairly large area in the graben east of the Muslingehjørnet fault (fig. 13). To the south of Krabbedalen, however, the exposures are poor and do not allow any detailed observations. Generally it seems that the number of well rounded basalt pebbles increases in that direction so as to form soft pebbly mudstones. It is supposed that between Ilivnerajive and Kíkiakajik the Krabbedalen Member comes to rest immediately in contact with the plateau basalts, and that the thickness of the member there increases to $100 \mathrm{~m}$ or more.

\section{Kap Brewster Formation}

The sediments described by Hassan (op. cit.) as the Kap Brewster 'series' are here formally renamed the Kap Brewster Formation. The formation begins with a basal sedimentary breccia up to $40 \mathrm{~m}$ thick, or with a basal conglomerate up to $15 \mathrm{~m}$ thick, resting directly upon basalt. The breccia consists of generally unworked basalt blocks up to $2 \mathrm{~m}$ in diameter interbedded with finer clastic material of the same character. The type of the deposit corresponds to that of a cliff breccia. The conglomerate consists of rounded or well rounded basalt fragments, much smaller than those in the breccia, and resembles gravel-lag concentrate of a river.

Above the basal breccia there occurs a complex of sediments $36 \mathrm{~m}$ thick, with an abundant shallow-marine to littoral fauna ('Chlamys beds' of Hassan), consisting of alternating psammites and fine psephites, black to grey in the lower part and brown-red in the upper part. The material has been derived from fragmented basalt flows. The age of the fossil-bearing deposits is probably Miocene (Hassan op. cit.).

The fossil-bearing sediments contact laterally with the basalt cliff of Muslingehjørnet. This is a normal sedimentary contact with the basalt and this is demonstrated by, among other things, large ostreid shells attached firmly to the basalt wall. 


\section{Faulting}

As a whole, the sediments of the Kap Brewster Formation appear related to highrelief topography, while those of the Kap Dalton Formation indicate a low-relief topography of the neighbouring land. The bottom breccia could be a cliff-foot talus formed along the Muslingehjørnet fault scarp just below the up-warped Søstrene block. The formation of this fault, and possibly also the Bopladsdalen and Kíkiakajik faults, could therefore correspond to the break in deposition between the 'Coeloma beds' (Lower Oligocene) and the 'Chlamys beds' (Miocene). In the Kap Brewster Formation the basal conglomerate is brecciated and veined with calcite, and the basal breccia is slickensided, while its stratification dips about $60^{\circ}$ WNW. The dip of the succeeding fossil-bearing strata is only $20^{\circ}-35^{\circ} \mathrm{W}$. There could be an angular unconformity amounting to about $30^{\circ}$ between the 'Chlamys beds' and the basal breccia, but unfortunately the contact of these is obscured by scree. The tilt of the fossil-bearing sediments is conformable with that of the adjacent basalt lava flows. It is supposed that the down-warping and rotation of the Kastellet block with respect to the horizontal Søstrene block was a continuous process which produced a thick zone of mylonite and crush-breccia along the Muslingehjørnet fault zone. This movement could have extended well into late Neogene time.

The direction of the eastern coast of Savoia Halvø is roughly the same as that of the Muslingehjørnet fault (fig. 13); its cliff line could correspond to an offshore fault in Danmark Strædet.

\section{References}

Beckinsale, R. D., Brooks, C. K. \& Rex, D. C. 1970: K-Ar ages for the Tertiary of East Greenland. Meddr dansk geol. Foren. 20, 27-37.

Fawcett, J. J., Rucklidge, J.C. \& Brooks, C. K. 1966: Geological expedition to the Tertiary basalt region of Scoresby Sund, East Greenland. Nature, Lond. 212, 603-604.

Hassan, M. Y. 1953: Tertiary faunas from Kap Brewster, East Greenland. Meddr Grønland $111,5,42 \mathrm{pp}$.

Mathiesen, F. J. 1932: Notes on some fossil plants from East Greenland (Cape Dalton, Turner Sound, Cape Brewster, and Sabine Island). Meddr Gronland 85, 4, 62 pp.

Ravn, J.P. J. 1933: New investigations of the Tertiary at Cape Dalton, East Greenland. Meddr Grønland 105, 1, 15 pp.

Tarling, D. H. 1967: The palaeomagnetic properties of some Tertiary lavas from East Greenland. Earth planet. Sci. Lett. 3, 81-88. 